\title{
The Persistent Labour-Market Effects of the Financial Crisis *
}

\author{
Marcus Mossfeldt ${ }^{\#}$
}

Pär Österholm*

\footnotetext{
* We are grateful to seminar participants at the National Institute of Economic Research for valuable comments on this paper.

\# National Institute of Economic Research, Box 3116, 10362 Stockholm, Sweden e-mail: marcus.mossfeldt@konj.se Phone: +46 84535943

* National Institute of Economic Research, Box 3116, 10362 Stockholm, Sweden e-mail: par.osterholm@konj.se Phone: +46 84535972

WORKING PAPER NR 117, MARCH 2010

PUBLISHED BY THE NATIONAL INSTITUTE OF ECONOMIC RESEARCH (NIER)
} 
NIER prepares analyses and forecasts of the Swedish and international economy and conducts related research. NIER is a government agency accountable to the Ministry of Finance and is financed largely by Swedish government funds. Like other government agencies, NIER has an independent status and is responsible for the assessments that it publishes.

The Working Paper series consists of publications of research reports and other detailed analyses. The reports may concern macroeconomic issues related to the forecasts of the institute, research in environmental economics, or problems of economic and statistical methods. Some of these reports are published in their final form in this series, whereas others are previews of articles that are subsequently published in international scholarly journals under the heading of Reprints. Reports in both of these series can be ordered free of charge. Most publications can also be downloaded directly from the NIER home page. 


\begin{abstract}
This paper estimates the effects of the financial crisis on the Swedish labour market. Using an unobserved components model and an external forecast, we estimate a future path for the NAIRU. Judging by this analysis, the labour market will be in equilibrium again in 2013. Linking the NAIRU to other labour-market variables through an estimated vector error correction model and population projections, it is found that this new equilibrium is associated with a smaller equilibrium labour force and lower equilibrium employment.
\end{abstract}

JEL Classification: E24

Keywords: Discouraged worker, Unobserved components, Cointegration 



\section{Summary in Swedish}

Finanskrisen har medfört att arbetslösheten stigit från 6 till 9 procent. Erfarenheterna från 1990-talskrisen samt ekonomisk teori indikerar att denna försvagning av arbetsmarknaden kommer att leda till långvariga negativa effekter på sysselsättning och arbetskraftsdeltagande. I denna arbetsrapport skattas effekterna effekterna av finanskrisen på den svenska arbetsmarknaden. I ett första steg skattas en så kallad unobserved components-modell för NAIRU. Modellen är uppbyggd så att den explicit avser att fånga upp hur konjunkturell arbetslöshet påverkar NAIRU. (Med

konjunkturell arbetslöshet menas faktisk arbetslöshets avvikelse från NAIRU.) I ett andra steg skattas det långsiktiga sambandet mellan arbetslöshet och arbetskraftsdeltagande med en så kallad kointegrationsmodell. I ett tredje steg används modellskattningarna i de två tidigare stegen för att beräkna de långsiktiga effekterna på arbetskraft och sysselsättning. Genom att använda en prognos för de kommande årens arbetslöshet kan ett estimat av finanskrisens effekter beräknas i förväg. Resultaten visar att den nya jämvikten är förknippad med ett lägre arbetskraftsdeltagande, lägre sysselsättning och en högre arbetslöshet. 



\section{Contents}

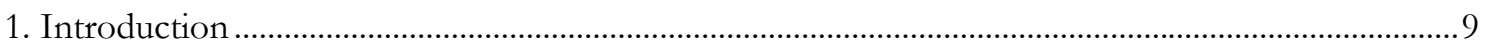

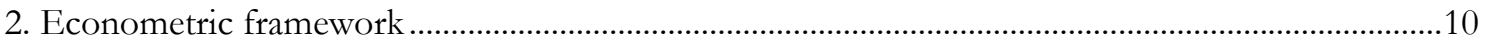

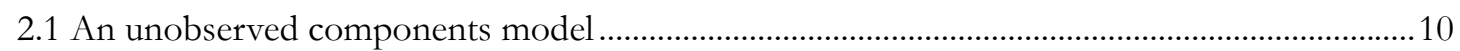

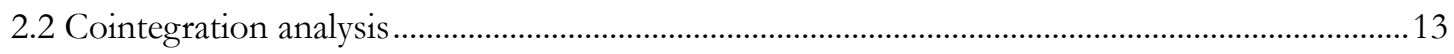

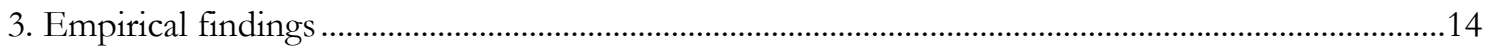

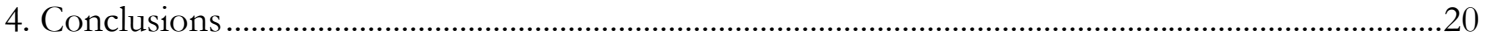





\section{Introduction}

The steep fall in aggregate demand in the wake of the financial crisis led to a rapid deterioration of the Swedish labour market. Between the summer of 2008 and the end of 2009 the unemployment rate rose from just below 6 percent to around 9 percent. The unemployment rate is widely expected to increase even further. According to the most recent forecast of the National Institute of Economic Research (NIER, 2009b), the unemployment rate will peak at above 10 percent in 2011. A natural question for policymakers and forecasters to ask under these circumstances is what the persistence effects of the crisis on the labour market might be.

The fact that business cycle fluctuations can cause permanent effects on, for example, unemployment and labour-force participation is well established in the academic literature. Explanations to why macroeconomic shocks can have long-lasting effects on the labour market include decay of human capital, discouragement and habituation; see, for example, Pissarides (1992) and Clark et al. (2001). Effects can also be due to the behaviour of unions in the wage bargaining process; see Blanchard and Summers (1986) and Gottfries and Horn (1987).

While negative economic shocks seemed to have long-lasting negative effects on the labour market in many OECD countries in the 1970s and 1980s, the Swedish unemployment rate was exceptionally low in the 1980s by international standards. However, between 1990 and 1993 it increased from around 2 to 11 percent. It took as long as until 1998 before the unemployment rate started to decrease reliably, reaching 6 percent in 2001. It is widely believed that this increase in unemployment was mainly caused by adverse macroeconomic shocks, including a fall in international demand and some policy mistakes. Part of the increase in unemployment can hence be argued to have been an effect of unsustainable economic polices in the past; see, for example, Holmlund (2009) for a discussion. Several studies have estimated the NAIRU in Sweden; see, for example, Lindblad (1997), Assarsson and Jansson (1998), Apel and Jansson (1999b) and Lindblad and Sellin (2003). A majority of the conducted studies show an increase in the NAIRU between the 1980s and the 1990s but these studies give us little information as to why the NAIRU increased. It can, however, be noted that it is difficult to identify sharp changes in structural factors - benefit levels, taxes, etcetera between the 1980s and the 1990s (Holmlund, 2009). Therefore, it is reasonable to conclude that at least part of the increase in the NAIRU in the 1990s was due to long-lasting effects of the aforementioned macroeconomic shocks.

The goal of this paper is twofold. First, the spill-over effect from the cyclical unemployment rate to the NAIRU in Sweden is estimated. We believe that such an effect is a relevant feature to allow for and our empirical approach is hence a step forward relative to the lion's share of the previous em- 
pirical literature studying the Swedish equilibrium unemployment rate. ${ }^{1}$ Second, we estimate longrun effects on the labour force and employment. Although the NAIRU is interesting in and of itself, the unemployment rate is not a perfect indicator of developments in the labour market (Murphy and Topel, 1997; Gustavsson and Österholm, 2006) and it is therefore of great value to have an estimate of the effects on equilibrium employment - and not just the equilibrium unemployment rate - in many cases. For example, when discussing the long-term stability of public finances in light of the ongoing crisis, employment is a far more interesting variable than the unemployment rate.

A novel feature of this paper is that it aims not only to estimate persistence effects ex post, but also ex ante. This is accomplished by incorporating extra-model information in terms of external forecasts of the unemployment rate and population. Our results suggest that the NAIRU will rise the next few years and that labour-force participation rate will decrease; the equilibrium labour force and equilibrium employment are predicted to fall. Qualitatively, these findings are obviously not surprising. A main contribution of the paper is hence to provide a framework in which the effects of the ongoing crisis on the labour market can be quantified.

The remainder of this paper is organised as follows: The econometric framework is described in Section 2. In Section 3, the empirical analysis is conducted and the results are discussed. Section 4 concludes.

\section{Econometric framework}

The empirical analysis is conducted in two stages. First, the NAIRU is estimated using an unobserved components model. Second, cointegration analysis is used to link the estimated NAIRU to the labour force and employment. The two stages are explained in detail below.

\subsection{An unobserved components model}

Unobserved components models have frequently been used in the empirical literature in order to estimate a time-varying NAIRU; see, for example, Gordon (1997) for an important contribution. The model employed in this paper takes its starting point in the framework of Apel and Jansson (1999a, 1999b); more specifically, the model is an extension of a model employed by Hjelm and Jönsson (2010). Importantly for our purposes, the model is extended with feedback from cyclical unemployment to the NAIRU in line with Jaeger and Parkinson (1994) and Assarsson and Jansson (1998).

\footnotetext{
${ }^{1}$ In this paper, the terms NAIRU and equlibrium unemployment rate are used synonymously.
} 
More specifically, the Phillips curve is given by

$$
\Delta \pi_{t}=\sum_{i=1}^{4} \phi_{i} \Delta \pi_{t-i}+\sum_{j=1}^{2} \tau_{j} u_{t-j}^{c}+\sum_{n=1}^{4} \boldsymbol{\theta}_{n}^{\prime} \mathbf{x}_{t-n}+\delta D_{t}+v_{t},
$$

where $\pi_{t}$ is the quarterly inflation rate and $u_{t}^{c}$ is cyclical unemployment. $\mathbf{x}_{t}$ is a vector of supply shock proxies and $D_{t}$ is a dummy variable which is 1 in 1993Q1 - the quarter in which Sveriges Riksbank declared that it would turn to inflation targeting - and zero otherwise.

The unemployment rate is decomposed into two unobservable components, a cyclical component, $u_{t}^{c}$, and a natural rate component, $u_{t}^{n}$, according to

$u_{t}=u_{t}^{c}+u_{t}^{n}$

Cyclical unemployment is modelled as an $\mathrm{AR}(2)$ process:

$u_{t}^{c}=\lambda_{1} u_{t-1}^{c}+\lambda_{2} u_{t-2}^{c}+\zeta_{t}$

This is a natural choice since it is the most parsimonious univariate specification that can generate reasonable cyclical fluctuations. The natural rate component is assumed to be a unit-root process which (potentially) is affected by cyclical unemployment.

$u_{t}^{n}=u_{t-1}^{n}+\kappa u_{t-2}^{c}+\omega_{t}$

By making the natural rate component a unit-root process, we allow for permanent level shifts in the NAIRU. This assumption has certain theoretical appeal since we expect some shocks - such as changes to benefit levels - to have permanent effects. It is also a reasonable modelling choice since most empirical studies find that the Swedish unemployment rate is a unit-root process; see, for 
example, Gustavsson and Österholm $(2007,2010) .{ }^{2} \kappa$ is a parameter of particular interest since it tells us to what extent cyclical unemployment spills over into the NAIRU. ${ }^{3}$

The output gap, specified in equation (5), is given by an Okun's law relation; this links cyclical fluctuations in unemployment to cyclical fluctuations in output.

$$
y_{t}-y_{t}^{p}=\psi_{1} u_{t}^{c}+\psi_{2} u_{t-1}^{c}+v_{t}
$$

Finally, potential output is a random walk with time-varying drift

$$
y_{t}^{p}=\gamma_{t-1}+y_{t-1}^{p}+\xi_{t},
$$

where the drift is modelled as a random walk process

$$
\gamma_{t}=\gamma_{t-1}+\chi_{t}
$$

This specification is chosen in order to allow for the possibility that the trend rate of growth has changed over time and is a common choice in the empirical literature; see, for example, Clark (1987), Kim and Nelson (1999) and Wang and Wang (2007).

Finally, the error terms, $v_{t}, \zeta_{t}, \omega_{t}, v_{t}, \xi_{t}$ and $\chi_{t}$ are assumed to be normally distributed shocks with zero mean and constant variances.

The unobserved components model described above can be used to provide an estimate of how the NAIRU has evolved over time within sample, that is, for $t=1, \ldots, T$. However, given an external forecast for the unemployment rate, the structure of the model also allows us to generate a future path for the NAIRU. To see this, note that an estimate of the NAIRU in $T+1$ can be calculated as $u_{T+1}^{n}=u_{T}^{n}+\kappa u_{T-1}^{c}$. Using the external forecast of the unemployment rate, a forecast of cyclical unemployment in $T+1$ can then be calculated as $u_{T+1}^{c}=u_{T+1}-u_{T+1}^{n}$. Estimates of the

\footnotetext{
2 The assumption also has some shortcomings. Perhaps most notable is the fact that a variable that is bounded between zero and one strictly speaking cannot be a linear unit-root process with an additive error term fulfilling standard assumptions. However, as argued in, for example, Österholm (2010), the approximation error from this assumption is expected to be negligible.

3 It can be noted that we rely on the second lag of cyclical unemployment in the equation for the natural rate component. Jaeger and Parkinson (1994) and Assarsson and Jansson (1998) relied on the first lag but we argue that hysteresis effects should come with more of a delay. This makes sense from a theoretical perspective since, for example, human capital depreciation should appear with a non-negligible lag. Admittedly though, using the first lag rather than the second generates a minor difference in the estimate of $\kappa$. Result is not reported but is available upon request.
} 
NAIRU and cyclical unemployment in $T+2$ can be generated as $u_{T+2}^{n}=u_{T+1}^{n}+\kappa u_{T}^{c}$ and $u_{T+2}^{c}=u_{T+2}-u_{T+2}^{n}$ and so on. In this paper, we rely on the unemployment rate forecast of the National Institute of Economic Research published in December 2009 for this exercise; we return to data issues in Section 3.

While the unobserved components model can be employed - together with an external forecast for the unemployment rate - to provide an estimate of the future effects on the NAIRU, there is often substantial interest in the effects on labour-force participation and employment. We next describe how the results from the unobserved components model can be used for this purpose.

\subsection{Cointegration analysis}

It is well known that labour-force participation is affected by unemployment. Both added- and discouraged-worker effects have found support empirically; see, for example, Mincer (1962), Fleisher and Rhodes (1976), Benati (2001), Juhn et al. (2001) and Stephens (2002). Recently, Österholm (2010) established a strong empirical relationship between unemployment and labour-force participation in Sweden. More specifically, it was shown that the unemployment and labour-force participation rates were cointegrated. A long-run relationship between these two variables is useful since it allows us to link a forecast of the NAIRU to a forecast of the labour force and employment.

Following the empirical analysis in Österholm (2010), we estimate the long-run relationship between the unemployment and labour-force participation rates using a cointegrated VAR model given by

$$
\Delta \mathbf{z}_{t}=\boldsymbol{\mu}+\boldsymbol{\Pi} \mathbf{z}_{t-1}+\sum_{i=1}^{p-1} \boldsymbol{\Gamma}_{i} \Delta \mathbf{z}_{t-i}+\boldsymbol{\varepsilon}_{t} .
$$

The $2 \mathrm{x} 1$ vector of dependent variables is given by $\mathbf{z}_{t}=\left(\begin{array}{ll}p_{t} & u_{t}\end{array}\right)^{\prime}$, where $p_{t}$ is the labour-force participation rate. In this setting, $u_{t}$ and $p_{t}$ are cointegrated if $r$ - the rank of the coefficient matrix $\boldsymbol{\Pi}-$ is equal to one. In such a case, there exist $2 x 1$ vectors $\boldsymbol{\alpha}$ and $\boldsymbol{\beta}$ each with rank one such 
that $\boldsymbol{\Pi}=\boldsymbol{\alpha} \boldsymbol{\beta}^{\prime}$ and $\boldsymbol{\beta}^{\prime} \mathbf{y}_{t}$ is stationary. The elements of $\boldsymbol{\alpha}$ are the adjustment parameters in the vector error correction model and $\boldsymbol{\beta}$ is the cointegrating vector. ${ }^{4}$

We assume that the labour-force participation rate is a unit-root process given by $p_{t}=p_{t}^{*}+p_{t}^{c}$, where the permanent component $p_{t}^{*}$ is a unit-root process, which we interpret as a time-varying equilibrium value, and the transitory component $p_{t}^{c}$ is a weakly stationary ARMA process. This means that the cointegrating vector (if established) describes the relationship between the NAIRU and $p_{t}^{*}$. The estimated cointegrating vector is used to generate a future value of $p_{t}^{*}$ that is consistent in the long run with a particular value of the NAIRU. The value at the future time point $T+H$ is calculated as $p_{T+H}^{*}=-\hat{\mu}-\hat{\beta}_{2} u_{T+H}^{n}$, where the cointegrating vector is normalised to have a coefficient of unity on the labour-force participation rate. If the estimate of $\beta_{2}$ is positive, a higher NAIRU is associated with a lower equilibrium labour-force participation rate in the long run.

The estimates of $u_{T+H}^{n}$ from the unobserved components-model and $p_{T+H}^{*}$ from the cointegrating relationship can finally be used together with population predictions (provided by Statistics Sweden) to translate these rates into number of people for equilibrium unemployment, equilibrium labour force and equilibrium employment. ${ }^{5}$ This exercise relies on identities for $i$ ) the labour-force participation rate, $p_{t}=P_{t} / B_{t}$, where $P_{t}$ is the labour force and $B_{t}$ the population in the age bracket 16 to 64 years, and ii) the and unemployment rate, $u_{t}=U_{t} / P_{t}$, where $U_{t}$ is the number of unemployed. Equilibrium labour force, equilibrium unemployment and equilibrium employment are calculated as $P_{T+H}^{*}=p_{T+H}^{*} B_{T+H}, U_{T+H}^{n}=u_{T+H}^{n} P_{T+H}^{*}$ and $E_{T+H}^{*}=P_{T+H}^{*}-U_{T+H}^{n}$ respectively.

\section{Empirical findings}

We first estimate the unobserved components model in equations (1) to (7) using maximum likelihood. Inflation is measured using the consumer price index excluding households' mortgage interest expenditures and the direct effects of changes in indirect taxes and subsidies (KPIX). Output is

\footnotetext{
4 Note that the constant term in equation (8) is restricted such that a constant term is allowed for in the cointegrating relationship, but no drift in the system. For a technical discussion regarding specification and estimation, see, for example, Johansen (1995).

${ }^{5}$ Population predictions are well known for having extremely small prediction errors and any uncertainty in our calculations stemming from these predictions is dwarfed by estimation uncertainty in the other steps. For a discussion regarding the use of population data in macroeconomics, see, for example, Lindh (2004).
} 
given by real GDP and the unemployment rate measured according to the ILO definition. $\mathbf{x}_{t}$ is a $3 \times 1$ vector consisting of real oil price changes, changes in the relative price of imports and changes in the real exchange rate (measured by the KIX index). The sample is 1970Q2 to 2009Q3.

Estimates of key parameters are given in Table 1. As was pointed out above, the estimate of $\kappa$ in equation (4) is of particular interest to us. The null hypothesis of this coefficient being equal to zero can be rejected in favour of the alternative hypothesis of it taking on a positive value at the ten percent level. The point estimate suggests that cyclical unemployment spills over into the NAIRU to a non-negligible extent. For example, in a quarter where cyclical unemployment is three percent, the NAIRU increases with approximately 0.12 percentage point. It should be kept in mind though that there is a fair degree of uncertainty associated with this parameter estimate.

Table 1. Estimated key parameters from unobserved components model.

\begin{tabular}{|c|c|}
\hline$\phi_{1}$ & $\begin{array}{l}-0.568 \\
(0.071)\end{array}$ \\
\hline$\phi_{2}$ & $\begin{array}{l}-0.290 \\
(0.103)\end{array}$ \\
\hline$\phi_{3}$ & $\begin{array}{l}-0.113 \\
(0.092)\end{array}$ \\
\hline$\phi_{4}$ & $\begin{array}{l}-0.252 \\
(0.087)\end{array}$ \\
\hline$\tau_{1}$ & $\begin{array}{l}-0.260 \\
(0.178)\end{array}$ \\
\hline$\tau_{2}$ & $\begin{array}{c}0.233 \\
(0.175)\end{array}$ \\
\hline$\lambda_{1}$ & $\begin{array}{c}1.886 \\
(0.042)\end{array}$ \\
\hline$\lambda_{2}$ & $\begin{array}{l}-0.907 \\
(0.040)\end{array}$ \\
\hline$\kappa$ & $\begin{array}{c}0.040 \\
(0.029)\end{array}$ \\
\hline$\psi_{1}$ & $\begin{array}{l}-3.794 \\
(0.726)\end{array}$ \\
\hline$\psi_{2}$ & $\begin{array}{c}2.499 \\
(0.781)\end{array}$ \\
\hline
\end{tabular}

Note: Sample is 1970 Q2 to 2009 Q3. Standard errors in parentheses ().

The model's estimate of the NAIRU is shown in Figure 1. Noteworthy is the very large increase in the NAIRU associated with the crisis of the 1990s; between 1992 and 1999 the NAIRU is judged to have risen with approximately 4.5 percentage points. The estimated NAIRU from this model looks realistic and we believe that it appears more reasonable than those of many other studies. For example, the NAIRU in Assarsson and Jansson (1998) moves around to such an extent that the cyclical component of the unemployment rate never is larger than 0.8 percent. The NAIRU in Lindblad and Sellin (2003), on the other hand, barely moves during the crisis of the 1990s. 
Figure 1. Unemployment rate and estimated NAIRU.

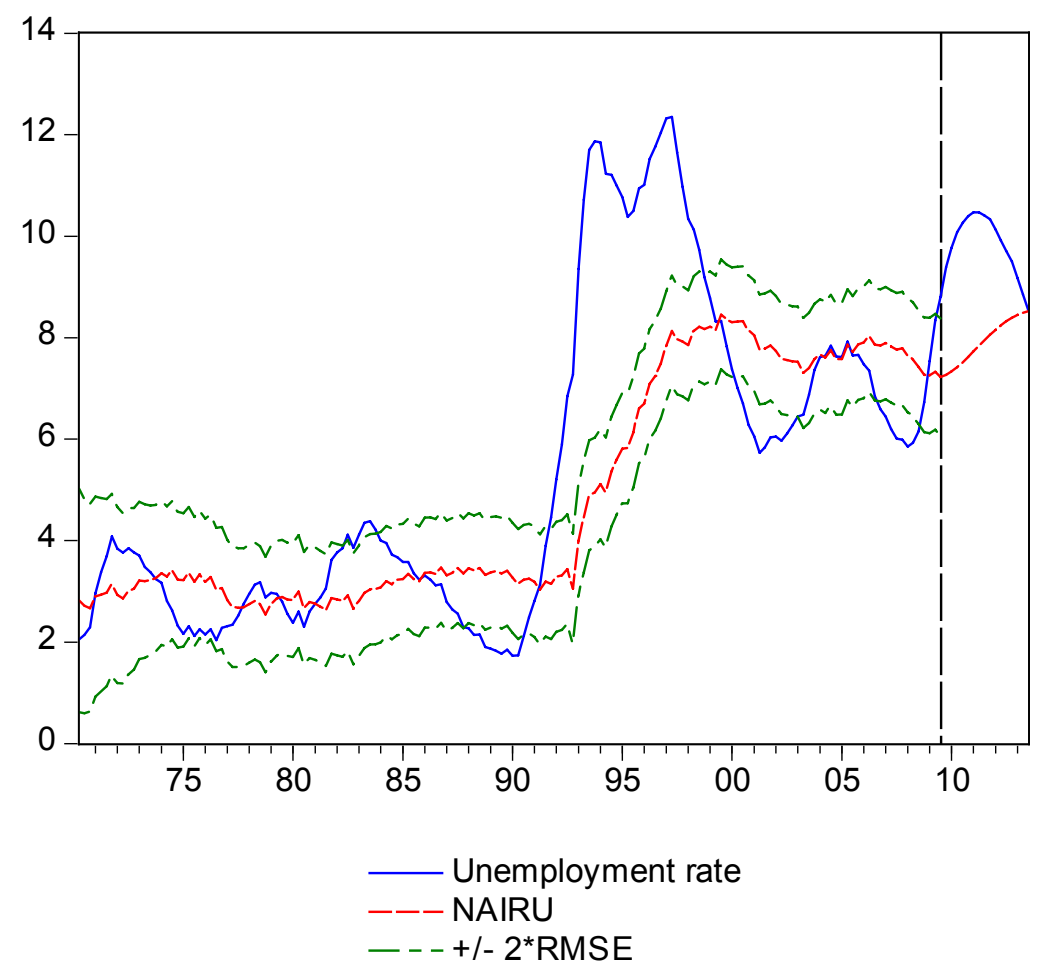

Note: Forecasts begin at dashed vertical line.

According to the forecast of the NIER (2009b), the present crisis will have the effect that the unemployment rate will keep increasing until the beginning of 2011. This forecast is also shown in Figure 1 and is used together with the estimated model to generate a future path for the NAIRU. As can be seen in Figure 1, this exercise suggests that the NAIRU will rise the next few years. The labour market will have reached a new equilibrium in late 2013 when cyclical unemployment is very close to zero.

Having calculated effects on the NAIRU above, we next turn to the cointegration analysis that will provide estimates of effects on other labour-market statistics. The sample used for this exercise is 1980Q1 to 2009Q3. ${ }^{6}$ In order to establish that cointegration methods are appropriate, we first test for unit roots in the data. Two different univariate unit-root tests are employed, namely the Augmented Dickey-Fuller test (Said and Dickey, 1984) and the KPSS test (Kwiatkowski et al., 1992).7 As can be seen from Table 2, the Augmented Dickey-Fuller test is not significant at the ten percent level for either variable. Turning to the KPSS test, it rejects the null of stationarity at the ten percent

\footnotetext{
${ }^{6}$ This is ten years less than when the unobserved components model was estimated. The reason a shorter sample is employed is that we are concerned that the behaviour of women during the 1970's is not representative of that today.

${ }^{7}$ Lag length in the Augmented Dickey-Fuller tests and vector autoregressions was established using the Akaike (1974) information criterion.
} 
level for both variables. Both unit-root tests hence suggest that the two variables are integrated of order one.

Table 2. Results from unit-root tests.

\begin{tabular}{ccc} 
& ADF & KPSS \\
$p_{t}$ & -1.02 & 0.84 \\
$u_{t}$ & -2.24 & 0.55 \\
\hline
\end{tabular}

Note: Sample is 1980Q1 to 2009Q3. ADF is the test statistic from the Augmented Dickey-Fuller test. KPSS is the test statistic from the KPSS test.

We test for cointegration between $p_{t}$ and $u_{t}$ using Johansen's (1988) maximum eigenvalue test; results are given in Table 3. Using a significance level of ten percent, the null hypothesis that the cointegrating rank is zero can be rejected whereas the null hypothesis that it is one cannot. ${ }^{8}$ We hence conclude that there exists one cointegrating vector. Since there might be some concern that the labour-force participation and unemployment rates do not have exact unit roots, we also test the additional restrictions $\boldsymbol{\beta}^{\prime}=\left(\begin{array}{ll}1 & 0\end{array}\right)$ and $\boldsymbol{\beta}^{\prime}=\left(\begin{array}{ll}0 & 1\end{array}\right)$ using a likelihood ratio test. This is done to ensure that the cointegrating vector found is not due to one of the variables being stationary; see Hjalmarsson and Österholm (2010) for a discussion of this issue. As can be seen from Table 3, both of these restrictions are rejected at the ten percent level.

Table 3. Results from cointegration test and restrictions on cointegrated VAR.

Test statistic

$\begin{array}{lr}H_{0}: r=0 & 13.92 \\ H_{0}: r=1 & 1.07\end{array}$

$H_{0}: \boldsymbol{\beta}^{\prime}=\left(\begin{array}{ll}1 & 0\end{array}\right)$

$H_{0}: \boldsymbol{\beta}^{\prime}=\left(\begin{array}{ll}0 & 1\end{array}\right)$

Note: Sample is 1980 Q1 to 2009Q3.

The estimated cointegrating vector from the model - where the coefficient on the labour-force participation rate has been normalised to unity - is shown in Table 4. This shows that there is a negative long-run relationship between labour-force participation and unemployment, that is, a higher unemployment rate is associated with a lower labour-force participation rate. This finding is consistent with discouraged-worker effects. The slope of the cointegrating vector suggests that a permanent increase in the NAIRU of one percentage points is associated with a decrease in the equilibrium labour-force participation rate with roughly one percentage point. The size of the effect

${ }^{8}$ If $H_{0}: r=1$ had been rejected, it would imply that both series are stationary; see, for example, Taylor and Sarno (1998). 
is hence reasonably close to the effect found by Elmeskov and Pichelmann (1993) using international cross-sectional data.

Table 4. Estimated key parameters vector error correction model.

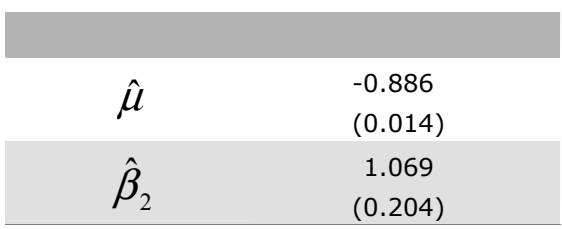

Note: Sample is 1980 Q1 to 2009 Q3. Standard errors in parentheses ().

We finally use the estimated cointegrating vector to calculate the effects of the crisis on some key labour-market variables. The increase in the NAIRU is roughly one percentage point and the fall in the equilibrium labour-force participation rate is a touch over one percentage point; see Table 5 .

Table 5. Estimated values for labour-market variables.

\begin{tabular}{cccc} 
& 201303 & $2008 Q 2$ & Difference \\
$u_{t}^{n}$ & 8.52 & 7.57 & 0.95 \\
$p_{t}^{*}$ & 79.52 & 80.54 & -1.02 \\
\hline
\end{tabular}

Note: NAIRU and equilibrium labour-force participation rate are given in percent.

By conducting the calculations outlined at the end of Section 2.2, the equilibrium labour force, equilibrium unemployment and equilibrium employment can be estimated. Table 6 presents these results, where we have chosen 2013Q3 and 2008Q2 as the time points for the comparison. 2013Q3 is chosen since it was suggested above that the labour market will be in equilibrium again then, whereas 2008Q2 is the last quarter before the mayhem broke loose in financial markets.

The first column of Table 6 simply gives the equilibrium values of 2013Q3 associated with $u_{t}^{n}$ and $p_{t}^{*}$ from the column denoted "2013Q3" in Table 5. In order to get an estimate of the effect of the crisis in number of people, we also calculate the values of $P_{t}^{*}, U_{t}^{n}$ and $E_{t}^{*}$ using the population of 2013Q3 but the NAIRU and equilibrium labour-force participation rate from the column denoted "2008Q2" in Table 5; this calculation tells us what $P_{t}^{*}, U_{t}^{n}$ and $E_{t}^{*}$ would have been if the NAIRU and equilibrium labour-force participation rate had not changed between 2008Q2 and 2013Q3. Accordingly, the difference between these two columns can be seen as the effect on these labour-market variables of the crisis. As can be seen from Table 6 , the fall in the equilibrium labour force is approximately 61000 people. Equilibrium unemployment increases with nearly 41000 people and equilibrium employment, accordingly, decreases with approximately 101000 people. 
Table 6. Estimated equilibrium values for labour-market variables in $2013 Q 3$.

\begin{tabular}{|c|c|c|c|}
\hline & $\begin{array}{l}\text { Using estimated } \\
\text { values of NAIRU } \\
\text { and equilibrium } \\
\text { labour-force par- } \\
\text { ticipation rate } \\
\text { from } 2013 Q 3\end{array}$ & $\begin{array}{l}\text { Using estimated } \\
\text { values of NAIRU } \\
\text { and equilibrium } \\
\text { labour-force par- } \\
\text { ticipation rate } \\
\text { from } 2008 Q 2\end{array}$ & Difference \\
\hline$P_{t}^{*}$ & 4751 & 4812 & -61 \\
\hline$U_{t}^{n}$ & 405 & 364 & 41 \\
\hline$E_{t}^{*}$ & 4346 & 4447 & -101 \\
\hline
\end{tabular}

Note: Equilibrium labour force, equilibrium unemployment and equilibrium employment are given in thousands of individuals. The differences do not add up due to rounding errors. In the first column, calculations have been carried out using the population of 2013Q3 and the NAIRU and equilibrium labour-force particpation rate of the column denoted "2013Q3" in Table 5. In the second column, calculations have been carried out using the population of 2013Q3 and the NAIRU and equilibrium labour-force particpation rate of the column denoted "2008Q2" in Table 5.

These estimates are of course associated with a large degree of uncertainty since they have been generated using two estimated models and external predictions for the unemployment rate and the population. An additional reason to take these numbers with a pinch of salt is that there are a number of pitfalls associated with the above conducted exercise. First, the models that are used to some extent rest on the assumption that no significant changes in how some parts of the economy work have taken place during the sample period. However, some changes in institutions during the sample period might be of importance. For example, the changes in stabilization policy objectives and the wage bargaining process during the sample period may have altered the Phillips-curve relationship over time.

Second, one could argue that the persistence effects are non-linear - that is, larger on the margin the higher cyclical unemployment. The unemployment rate is forecasted to reach lower levels during this crisis compared to the crisis in the 1990s. This might imply that the estimated spill-over effect from cyclical unemployment to the NAIRU might overstate the effect of the current crisis. However, the high unemployment in the aftermath of the crisis in the 1990s only comprises a rather small part of the whole sample period. Therefore, it is an open question if this is the case.

Third, there are reasons to believe that the effects of the ongoing crisis will be somewhat different from what the model suggests due to changes of some key institutional features between the sample period and the forecasting period. There are, for example, stronger economic incentives to stay in the labour force due to lower unemployment benefit levels in the coming years than the average of the sample period (NIER, 2009a). The fact that income taxes that stem from work have been significantly lowered in recent years, particularly for low income earners, might also work in this direction. There is also reason to believe that a smaller proportion of the people who become unemployed will leave the labour force for early retirement in the aftermath of the present crisis compared to the one in the early 1990s. These policy changes imply not only that negative effects on 
the labour force could be smaller than the model suggests, but also that the effects on NAIRU might be larger.

Finally, it can also be noted that the estimated equilibrium that is reached in 2013 only can serve as an approximation of the long-lasting effects of the crises. Cohort effects make it likely that the persistence effects diminish somewhat in the years after 2013 due to the fact that some of those who lose their jobs are approaching retirement age.

Despite the above mentioned issues, it is nevertheless useful to provide policymakers and forecasters with point estimates of the persistence effects; even though most forecasts published are judgemental, a starting point for the discussion is always needed. Knowing the shortcomings of the employed empirical framework, model-based results can be highly valuable for this purpose.

\section{Conclusions}

In this paper, we have estimated the persistence effects on the labour market of the ongoing crisis. Results indicate that these effects could be substantial. Between 2008 and 2013, the NAIRU is predicted to rise with roughly one percentage point and the equilibrium labour-force participation rate to fall by a similar amount. The increase in the NAIRU and fall in the equilibrium labour-force participation rate are also associated with falls in the equilibrium labour force and equilibrium employment of approximately 61000 and 101000 people respectively.

The increase in the NAIRU due to the ongoing crisis is smaller than the estimated increase in the NAIRU associated with the crisis in the early 1990s. This is mainly due to the present crisis being predicted to be smaller in magnitude and have a shorter duration. The fact that the persistence effects nevertheless could be non-negligible is relevant information for policymakers. Additional active measures to keep the unemployment rate down during the ongoing crisis could be considered since such actions might pay off in the long run. 


\section{References}

Akaike, H. (1974), "A New Look at the Statistical Model Identification", IEEE Transactions on Automatic Control 19, 716-723.

Apel, M. and Jansson, P. (1999a), “A Theory-Consistent System Approach for Estimating Potential Output and the NAIRU”, Economics Letters 64, 271-275.

Apel, M. and Jansson, P. (1999b), "System Estimates of Potential Output and the NAIRU”, Empirical Economics 24, 373-388.

Assarsson, B. and Jansson, P. (1998), “Unemployment Persistence: The Case of Sweden”, Applied Economics Letters 5, 25-29.

Benati, L. (2001), "Some Empirical Evidence on the 'Discouraged Worker' Effect”, Economics Letters $70,387-395$.

Blanchard, O. J. and Summers, L. H. (1986), "Hysteresis and the European Unemployment Problem”, NBER Macroeconomics Annual 1, 15-78.

Clark, A. E., Georgellis, Y. and Sanfey, P. (2001), "Scarring: The Psychological Impact of Past Unemployment", Economica 68, 221 - 241.

Clark, P. K. (1987), “The Cyclical Component of the US Economic Activity”, Quarterly Journal of Economics 102, 797-814.

Elmeskov, J. and Pichelmann, K. (1993), "Interpreting Unemployment: The Role of Labour-Force Participation", OECD Economic Studies 21, OECD.

Fleisher, B. M. and Rhodes, G. (1976), "Unemployment and the Labor Force Participation of Married Men and Women: A Simultaneous Model”, Review of Economics and Statistics 58, 398-406.

Gordon, R. J. (1997), "The Time-Varying NAIRU and Its Implications for Economic Policy”, Journal of Economic Perspectives 11, 11-32.

Gottfries, N. and Horn, H. (1987), "Wage Formation and the Persistence of Unemployment", Economic Journal 97, 877-884.

Gustavsson, M. and Österholm, P. (2006), "The Informational Value of Unemployment Statistics: A Note on the Time Series Properties of Participation Rates”, Economics Letters 92, 428-433.

Gustavsson, M. and Österholm, P. (2007), "Does Unemployment Hysteresis Equal Employment Hysteresis?”, Economic Record 83, 159-173.

Gustavsson, M. and Österholm, P. (2010), "The Presence of Unemployment Hysteresis in the OECD: What Can We Learn from Out-of-Sample Forecasts?”, Empirical Economics 38, 779792.

Hjalmarsson, E. and Österholm, P. (2010), "Testing for Cointegration Using the Johansen Methodology when Variables Are Near-Integrated: Size Distortions and Partial Remedies", Forthcoming in Empirical Economics, DOI: 10.1007/s00181-009-0294-6. 
Hjelm, G. and Jönsson, K. (2010), "In Search of a Method for Measuring the Output Gap of the Swedish Economy”, Working Paper No. 115, National Institute of Economic Research.

Holmlund, B. (2009), "The Swedish Unemployment Experience”, Oxford Review of Economic Policy 25, 109-125.

Jaeger, A. and Parkinson, M. (1994), "Some Evidence on Hysteresis in Unemployment Rates", European Economic Review 38, 329-342.

Johansen, S. (1988), "Statistical Analysis of Cointegration Vectors", Journal of Economic Dynamics and Control 12, 231-254.

Johansen, S. (1995), Likelihood-Based Inference in Cointegrated Vector Autoregressive Models, Oxford University Press, New York.

Juhn, C., Murphy, K. M., Topel, R. H. (2002), "Current Unemployment, Historically Contemplated", Brookings Papers on Economic Activity 1:2002, 79-116.

Kim, C. J. and Nelson, C. R. (1999), "Friedman's Plucking Model of Business Fluctuations: Tests and Estimations of Permanent and Transitory Components", Journal of Money, Credit and Banking 31, 317-334.

Kwiatkowski, D., Phillips, P.C.B., Schmidt, P. and Shin, Y. (1992), “Testing the Null Hypothesis of Stationarity Against the Alternative of a Unit Root: How Sure are We That Economic Time Series Have a Unit Root?", Journal of Econometrics 54, 159-178.

Lindblad, H. (1997), "Persistence in Swedish Unemployment Rates”, Working Paper 1997:3, Department of Economics, Stockholm University.

Lindblad, H. och Sellin, P. (2003), "The Equilibrium Rate of Unemployment and the Real Exchange Rate: An Unobserved Components System Approach", Working Paper No. 152, Sveriges Riksbank.

Lindh, T. (2004), "Medium-Term Forecasts of Potential GDP and Inflation Using Age Structure Information", Journal of Forecasting 23, 19-49.

Mincer, J. (1962). "Labor Force Participation of Married Women: A Study of Labor Supply", In: Lewis, H. G. (ed), Aspects of Labor Economics, Princeton University Press, Princeton.

Mortensen, D. T. (1986), "Job Search and Labor Market Analysis", In: Ashenfelter, O. and Layard, R. (eds), Handbook of Labor Economics, Vol. 2, Elsevier, Amsterdam.

Murphy, K. M. and Topel, R. (1997), "Unemployment and Nonemployment", American Economic Review 87, 295-300.

National Institute of Economic Research (2009a), The Swedish Economy, March 2009.

National Institute of Economic Research (2009b), The Swedish Economy, December 2009.

Österholm, P. (2010), "Unemployment and Labour-Force Participation in Sweden", Economics Letters 106, 205-208. 
Pissarides, C. A. (1992), "Loss of Skill During Unemployment and the Persistence of Employment Shocks", Quarterly Journal of Economics 107, 1371-1391.

Said, S. E. and Dickey, D. A. (1984), "Testing for Unit Roots in Autoregressive Moving Average Models of Unknown Order”, Biometrika 71, 599-607.

Stephens, M. (2002), "Worker Displacement and the Added Worker Effect", Journal of Labor Economics 20, 504-537.

Taylor, M. P. and Sarno L. (1998), "The Behaviour of Real Exchange Rates During the PostBretton Woods Period", Journal of International Economics 46, 281-312.

Wang, P. and Wang, P. (2007), "Business Cycle Trends, Cycles and Growth Revisited: With Applications to G7 Economies", Australian Economic Papers 46, 282-299. 


\section{Titles in the Working Paper Series}

\begin{tabular}{|c|c|c|c|}
\hline No & Author & Title & Year \\
\hline 1 & $\begin{array}{l}\text { Warne, Anders and } \\
\text { Anders Vredin }\end{array}$ & $\begin{array}{l}\text { Current Account and Business Cycles: Stylized Facts } \\
\text { for Sweden }\end{array}$ & 1989 \\
\hline 2 & Östblom, Göran & $\begin{array}{l}\text { Change in Technical Structure of the Swedish Econ- } \\
\text { omy }\end{array}$ & 1989 \\
\hline 3 & Söderling, Paul & $\begin{array}{l}\text { Mamtax. A Dynamic CGE Model for Tax Reform } \\
\text { Simulations }\end{array}$ & 1989 \\
\hline 4 & $\begin{array}{l}\text { Kanis, Alfred and Alek- } \\
\text { sander Markowski }\end{array}$ & $\begin{array}{l}\text { The Supply Side of the Econometric Model of the } \\
\text { NIER }\end{array}$ & 1990 \\
\hline 5 & Berg, Lennart & The Financial Sector in the SNEPQ Model & 1991 \\
\hline 6 & $\begin{array}{l}\text { Ågren, Anders and Bo } \\
\text { Jonsson }\end{array}$ & $\begin{array}{l}\text { Consumer Attitudes, Buying Intentions and Con- } \\
\text { sumption Expenditures. An Analysis of the Swedish } \\
\text { Household Survey Data }\end{array}$ & 1991 \\
\hline 7 & $\begin{array}{l}\text { Berg, Lennart and } \\
\text { Reinhold Bergström }\end{array}$ & $\begin{array}{l}\text { A Quarterly Consumption Function for Sweden } \\
\text { 1979-1989 }\end{array}$ & 1991 \\
\hline 8 & Öller, Lars-Erik & $\begin{array}{l}\text { Good Business Cycle Forecasts- A Must for Stabili- } \\
\text { zation Policies }\end{array}$ & 1992 \\
\hline 9 & $\begin{array}{l}\text { Jonsson, Bo and Anders } \\
\text { Ågren }\end{array}$ & $\begin{array}{l}\text { Forecasting Car Expenditures Using Household } \\
\text { Survey Data }\end{array}$ & 1992 \\
\hline 10 & $\begin{array}{l}\text { Löfgren, Karl-Gustaf, } \\
\text { Bo Ranneby and Sara } \\
\text { Sjöstedt }\end{array}$ & $\begin{array}{l}\text { Forecasting the Business Cycle Not Using Minimum } \\
\text { Autocorrelation Factors }\end{array}$ & 1992 \\
\hline 11 & Gerlach, Stefan & $\begin{array}{l}\text { Current Quarter Forecasts of Swedish GNP Using } \\
\text { Monthly Variables }\end{array}$ & 1992 \\
\hline 12 & Bergström, Reinhold & $\begin{array}{l}\text { The Relationship Between Manufacturing Produc- } \\
\text { tion and Different Business Survey Series in Sweden }\end{array}$ & 1992 \\
\hline 13 & $\begin{array}{l}\text { Edlund, Per-Olov and } \\
\text { Sune Karlsson }\end{array}$ & $\begin{array}{l}\text { Forecasting the Swedish Unemployment Rate: VAR } \\
\text { vs. Transfer Function Modelling }\end{array}$ & 1992 \\
\hline 14 & $\begin{array}{l}\text { Rahiala, Markku and } \\
\text { Timo Teräsvirta }\end{array}$ & $\begin{array}{l}\text { Business Survey Data in Forecasting the Output of } \\
\text { Swedish and Finnish Metal and Engineering Indus- } \\
\text { tries: A Kalman Filter Approach }\end{array}$ & 1992 \\
\hline 15 & $\begin{array}{l}\text { Christofferson, Anders, } \\
\text { Roland Roberts and } \\
\text { Ulla Eriksson }\end{array}$ & $\begin{array}{l}\text { The Relationship Between Manufacturing and Vari- } \\
\text { ous BTS Series in Sweden Illuminated by Frequency } \\
\text { and Complex Demodulate Methods }\end{array}$ & 1992 \\
\hline 16 & Jonsson, Bo & $\begin{array}{l}\text { Sample Based Proportions as Values on an Inde- } \\
\text { pendent Variable in a Regression Model }\end{array}$ & 1992 \\
\hline 17 & Öller, Lars-Erik & $\begin{array}{l}\text { Eliciting Turning Point Warnings from Business } \\
\text { Surveys }\end{array}$ & 1992 \\
\hline 18 & Forster, Margaret M & $\begin{array}{l}\text { Volatility, Trading Mechanisms and International } \\
\text { Cross-Listing }\end{array}$ & 1992 \\
\hline 19 & Jonsson, Bo & $\begin{array}{l}\text { Prediction with a Linear Regression Model and Er- } \\
\text { rors in a Regressor }\end{array}$ & 1992 \\
\hline 20 & $\begin{array}{l}\text { Gorton, Gary and Rich- } \\
\text { ard Rosen }\end{array}$ & $\begin{array}{l}\text { Corporate Control, Portfolio Choice, and the De- } \\
\text { cline of Banking }\end{array}$ & 1993 \\
\hline 21 & $\begin{array}{l}\text { Gustafsson, Claes- } \\
\text { Håkan and Åke Holmén }\end{array}$ & $\begin{array}{l}\text { The Index of Industrial Production - A Formal } \\
\text { Description of the Process Behind it }\end{array}$ & 1993 \\
\hline 22 & Karlsson, Tohmas & $\begin{array}{l}\text { A General Equilibrium Analysis of the Swedish Tax } \\
\text { Reforms 1989-1991 }\end{array}$ & 1993 \\
\hline
\end{tabular}




\begin{tabular}{|c|c|c|c|}
\hline 23 & Jonsson, Bo & $\begin{array}{l}\text { Forecasting Car Expenditures Using Household } \\
\text { Survey Data- A Comparison of Different Predictors }\end{array}$ & 1993 \\
\hline 24 & $\begin{array}{l}\text { Gennotte, Gerard and } \\
\text { Hayne Leland }\end{array}$ & Low Margins, Derivative Securitites and Volatility & 1993 \\
\hline 25 & $\begin{array}{l}\text { Boot, Arnoud W.A. and } \\
\text { Stuart I. Greenbaum }\end{array}$ & Discretion in the Regulation of U.S. Banking & 1993 \\
\hline 26 & $\begin{array}{l}\text { Spiegel, Matthew and } \\
\text { Deane J. Seppi }\end{array}$ & $\begin{array}{l}\text { Does Round-the-Clock Trading Result in Pareto } \\
\text { Improvements? }\end{array}$ & 1993 \\
\hline 27 & Seppi, Deane J. & $\begin{array}{l}\text { How Important are Block Trades in the Price Dis- } \\
\text { covery Process? }\end{array}$ & 1993 \\
\hline 28 & Glosten, Lawrence R. & $\begin{array}{l}\text { Equilibrium in an Electronic Open Limit Order } \\
\text { Book }\end{array}$ & 1993 \\
\hline 29 & $\begin{array}{l}\text { Boot, Arnoud W.A., } \\
\text { Stuart I Greenbaum and } \\
\text { Anjan V. Thakor }\end{array}$ & Reputation and Discretion in Financial Contracting & 1993 \\
\hline $30 \mathrm{a}$ & Bergström, Reinhold & $\begin{array}{l}\text { The Full Tricotomous Scale Compared with Net } \\
\text { Balances in Qualitative Business Survey Data - Ex- } \\
\text { periences from the Swedish Business Tendency } \\
\text { Surveys }\end{array}$ & 1993 \\
\hline $30 \mathrm{~b}$ & Bergström, Reinhold & $\begin{array}{l}\text { Quantitative Production Series Compared with } \\
\text { Qualiative Business Survey Series for Five Sectors of } \\
\text { the Swedish Manufacturing Industry }\end{array}$ & 1993 \\
\hline 31 & $\begin{array}{l}\text { Lin, Chien-Fu Jeff and } \\
\text { Timo Teräsvirta }\end{array}$ & $\begin{array}{l}\text { Testing the Constancy of Regression Parameters } \\
\text { Against Continous Change }\end{array}$ & 1993 \\
\hline 32 & $\begin{array}{l}\text { Markowski, Aleksander } \\
\text { and Parameswar Nan- } \\
\text { dakumar }\end{array}$ & $\begin{array}{l}\text { A Long-Run Equilibrium Model for Sweden. The } \\
\text { Theory Behind the Long-Run Solution to the } \\
\text { Econometric Model KOSMOS }\end{array}$ & 1993 \\
\hline 33 & $\begin{array}{l}\text { Markowski, Aleksander } \\
\text { and Tony Persson }\end{array}$ & $\begin{array}{l}\text { Capital Rental Cost and the Adjustment for the Ef- } \\
\text { fects of the Investment Fund System in the Econo- } \\
\text { metric Model Kosmos }\end{array}$ & 1993 \\
\hline 34 & $\begin{array}{l}\text { Kanis, Alfred and Bha- } \\
\text { rat Barot }\end{array}$ & $\begin{array}{l}\text { On Determinants of Private Consumption in Swe- } \\
\text { den }\end{array}$ & 1993 \\
\hline 35 & $\begin{array}{l}\text { Kääntä, Pekka and } \\
\text { Christer Tallbom }\end{array}$ & $\begin{array}{l}\text { Using Business Survey Data for Forecasting Swedish } \\
\text { Quantitative Business Cycle Varable. A Kalman } \\
\text { Filter Approach }\end{array}$ & 1993 \\
\hline 36 & $\begin{array}{l}\text { Ohlsson, Henry and } \\
\text { Anders Vredin }\end{array}$ & $\begin{array}{l}\text { Political Cycles and Cyclical Policies. A New Test } \\
\text { Approach Using Fiscal Forecasts }\end{array}$ & 1993 \\
\hline 37 & $\begin{array}{l}\text { Markowski, Aleksander } \\
\text { and Lars Ernsäter }\end{array}$ & $\begin{array}{l}\text { The Supply Side in the Econometric Model KOS- } \\
\text { MOS }\end{array}$ & 1994 \\
\hline 38 & $\begin{array}{l}\text { Gustafsson, Claes- } \\
\text { Håkan }\end{array}$ & $\begin{array}{l}\text { On the Consistency of Data on Production, Deliver- } \\
\text { ies, and Inventories in the Swedish Manufacturing } \\
\text { Industry }\end{array}$ & 1994 \\
\hline 39 & $\begin{array}{l}\text { Rahiala, Markku and } \\
\text { Tapani Kovalainen }\end{array}$ & $\begin{array}{l}\text { Modelling Wages Subject to Both Contracted In- } \\
\text { crements and Drift by Means of a Simultaneous- } \\
\text { Equations Model with Non-Standard Error Struc- } \\
\text { ture }\end{array}$ & 1994 \\
\hline 40 & $\begin{array}{l}\text { Öller, Lars-Erik and } \\
\text { Christer Tallbom }\end{array}$ & $\begin{array}{l}\text { Hybrid Indicators for the Swedish Economy Based } \\
\text { on Noisy Statistical Data and the Business Tendency } \\
\text { Survey }\end{array}$ & 1994 \\
\hline
\end{tabular}




\begin{tabular}{|c|c|c|c|}
\hline 41 & Östblom, Göran & $\begin{array}{l}\text { A Converging Triangularization Algorithm and the } \\
\text { Intertemporal Similarity of Production Structures }\end{array}$ & 1994 \\
\hline $42 \mathrm{a}$ & Markowski, Aleksander & $\begin{array}{l}\text { Labour Supply, Hours Worked and Unemployment } \\
\text { in the Econometric Model KOSMOS }\end{array}$ & 1994 \\
\hline $42 \mathrm{~b}$ & Markowski, Aleksander & $\begin{array}{l}\text { Wage Rate Determination in the Econometric } \\
\text { Model KOSMOS }\end{array}$ & 1994 \\
\hline 43 & $\begin{array}{l}\text { Ahlroth, Sofia, Anders } \\
\text { Björklund and Anders } \\
\text { Forslund }\end{array}$ & The Output of the Swedish Education Sector & 1994 \\
\hline $44 \mathrm{a}$ & Markowski, Aleksander & $\begin{array}{l}\text { Private Consumption Expenditure in the Econo- } \\
\text { metric Model KOSMOS }\end{array}$ & 1994 \\
\hline 44b & Markowski, Aleksander & $\begin{array}{l}\text { The Input-Output Core: Determination of Inven- } \\
\text { tory Investment and Other Business Output in the } \\
\text { Econometric Model KOSMOS }\end{array}$ & 1994 \\
\hline 45 & Bergström, Reinhold & $\begin{array}{l}\text { The Accuracy of the Swedish National Budget Fore- } \\
\text { casts 1955-92 }\end{array}$ & 1995 \\
\hline 46 & SjöÖ, Boo & $\begin{array}{l}\text { Dynamic Adjustment and Long-Run Economic } \\
\text { Stability }\end{array}$ & 1995 \\
\hline $47 \mathrm{a}$ & Markowski, Aleksander & $\begin{array}{l}\text { Determination of the Effective Exchange Rate in } \\
\text { the Econometric Model KOSMOS }\end{array}$ & 1995 \\
\hline $47 \mathrm{~b}$ & Markowski, Aleksander & $\begin{array}{l}\text { Interest Rate Determination in the Econometric } \\
\text { Model KOSMOS }\end{array}$ & 1995 \\
\hline 48 & Barot, Bharat & $\begin{array}{l}\text { Estimating the Effects of Wealth, Interest Rates and } \\
\text { Unemployment on Private Consumption in Sweden }\end{array}$ & 1995 \\
\hline 49 & Lundvik, Petter & Generational Accounting in a Small Open Economy & 1996 \\
\hline 50 & $\begin{array}{l}\text { Eriksson, Kimmo, Jo- } \\
\text { han Karlander and Lars- } \\
\text { Erik Öller }\end{array}$ & Hierarchical Assignments: Stability and Fairness & 1996 \\
\hline 51 & Url, Thomas & Internationalists, Regionalists, or Eurocentrists & 1996 \\
\hline 52 & Ruist, Erik & Temporal Aggregation of an Econometric Equation & 1996 \\
\hline 53 & Markowski, Aleksander & $\begin{array}{l}\text { The Financial Block in the Econometric Model } \\
\text { KOSMOS }\end{array}$ & 1996 \\
\hline 54 & Östblom, Göran & $\begin{array}{l}\text { Emissions to the Air and the Allocation of GDP: } \\
\text { Medium Term Projections for Sweden. In Conflict } \\
\text { with the Goals of } \mathrm{SO}_{2}, \mathrm{SO}_{2} \text { and NOX Emissions for } \\
\text { Year } 2000\end{array}$ & 1996 \\
\hline 55 & $\begin{array}{l}\text { Koskinen, Lasse, Alek- } \\
\text { sander Markowski, Pa- } \\
\text { rameswar Nandakumar } \\
\text { and Lars-Erik Öller }\end{array}$ & Three Seminar Papers on Output Gap & 1997 \\
\hline 56 & $\begin{array}{l}\text { Oke, Timothy and Lars- } \\
\text { Erik Öller }\end{array}$ & Testing for Short Memory in a VARMA Process & 1997 \\
\hline 57 & $\begin{array}{l}\text { Johansson, Anders and } \\
\text { Karl-Markus Modén }\end{array}$ & Investment Plan Revisions and Share Price Volatility & 1997 \\
\hline 58 & Lyhagen, Johan & $\begin{array}{l}\text { The Effect of Precautionary Saving on Consump- } \\
\text { tion in Sweden }\end{array}$ & 1998 \\
\hline 59 & $\begin{array}{l}\text { Koskinen, Lasse and } \\
\text { Lars-Erik Öller }\end{array}$ & $\begin{array}{l}\text { A Hidden Markov Model as a Dynamic Bayesian } \\
\text { Classifier, with an Application to Forecasting Busi- } \\
\text { ness-Cycle Turning Points }\end{array}$ & 1998 \\
\hline
\end{tabular}




\begin{tabular}{|c|c|c|c|}
\hline 60 & $\begin{array}{l}\text { Kragh, Börje and Alek- } \\
\text { sander Markowski }\end{array}$ & $\begin{array}{l}\text { Kofi - a Macromodel of the Swedish Financial Mar- } \\
\text { kets }\end{array}$ & 1998 \\
\hline 61 & $\begin{array}{l}\text { Gajda, Jan B. and Alek- } \\
\text { sander Markowski }\end{array}$ & $\begin{array}{l}\text { Model Evaluation Using Stochastic Simulations: The } \\
\text { Case of the Econometric Model KOSMOS }\end{array}$ & 1998 \\
\hline 62 & Johansson, Kerstin & Exports in the Econometric Model KOSMOS & 1998 \\
\hline 63 & Johansson, Kerstin & $\begin{array}{l}\text { Permanent Shocks and Spillovers: A Sectoral Ap- } \\
\text { proach Using a Structural VAR }\end{array}$ & 1998 \\
\hline 64 & $\begin{array}{l}\text { Öller, Lars-Erik and } \\
\text { Bharat Barot }\end{array}$ & $\begin{array}{l}\text { Comparing the Accuracy of European GDP Fore- } \\
\text { casts }\end{array}$ & 1999 \\
\hline 65 & $\begin{array}{l}\text { Huhtala, Anni and Eva } \\
\text { Samakovlis }\end{array}$ & $\begin{array}{l}\text { Does International Harmonization of Environ- } \\
\text { mental Policy Instruments Make Economic Sense? } \\
\text { The Case of Paper Recycling in Europe }\end{array}$ & 1999 \\
\hline 66 & Nilsson, Charlotte & $\begin{array}{l}\text { A Unilateral Versus a Multilateral Carbon Dioxide } \\
\text { Tax - A Numerical Analysis With The European } \\
\text { Model GEM-E3 }\end{array}$ & 1999 \\
\hline 67 & $\begin{array}{l}\text { Braconier, Henrik and } \\
\text { Steinar Holden }\end{array}$ & $\begin{array}{l}\text { The Public Budget Balance - Fiscal Indicators and } \\
\text { Cyclical Sensitivity in the Nordic Countries }\end{array}$ & 1999 \\
\hline 68 & Nilsson, Kristian & $\begin{array}{l}\text { Alternative Measures of the Swedish Real Exchange } \\
\text { Rate }\end{array}$ & 1999 \\
\hline 69 & Östblom, Göran & $\begin{array}{l}\text { An Environmental Medium Term Economic Model } \\
\text { - EMEC }\end{array}$ & 1999 \\
\hline 70 & $\begin{array}{l}\text { Johnsson, Helena and } \\
\text { Peter Kaplan }\end{array}$ & $\begin{array}{l}\text { An Econometric Study of Private Consumption } \\
\text { Expenditure in Sweden }\end{array}$ & 1999 \\
\hline 71 & $\begin{array}{l}\text { Arai, Mahmood and } \\
\text { Fredrik Heyman }\end{array}$ & $\begin{array}{l}\text { Permanent and Temporary Labour: Job and Worker } \\
\text { Flows in Sweden 1989-1998 }\end{array}$ & 2000 \\
\hline 72 & $\begin{array}{l}\text { Öller, Lars-Erik and } \\
\text { Bharat Barot }\end{array}$ & $\begin{array}{l}\text { The Accuracy of European Growth and Inflation } \\
\text { Forecasts }\end{array}$ & 2000 \\
\hline 73 & Ahlroth, Sofia & $\begin{array}{l}\text { Correcting Net Domestic Product for Sulphur Diox- } \\
\text { ide and Nitrogen Oxide Emissions: Implementation } \\
\text { of a Theoretical Model in Practice }\end{array}$ & 2000 \\
\hline 74 & $\begin{array}{l}\text { Andersson, Michael K. } \\
\text { And Mikael P. Greden- } \\
\text { hoff }\end{array}$ & $\begin{array}{l}\text { Improving Fractional Integration Tests with Boot- } \\
\text { strap Distribution }\end{array}$ & 2000 \\
\hline 75 & $\begin{array}{l}\text { Nilsson, Charlotte and } \\
\text { Anni Huhtala }\end{array}$ & $\begin{array}{l}\text { Is } \mathrm{CO}_{2} \text { Trading Always Beneficial? A CGE-Model } \\
\text { Analysis on Secondary Environmental Benefits }\end{array}$ & 2000 \\
\hline 76 & Skånberg, Kristian & $\begin{array}{l}\text { Constructing a Partially Environmentally Adjusted } \\
\text { Net Domestic Product for Sweden } 1993 \text { and } 1997\end{array}$ & 2001 \\
\hline 77 & $\begin{array}{l}\text { Huhtala, Anni, Annie } \\
\text { Toppinen and Mattias } \\
\text { Boman, }\end{array}$ & $\begin{array}{l}\text { An Environmental Accountant's Dilemma: Are } \\
\text { Stumpage Prices Reliable Indicators of Resource } \\
\text { Scarcity? }\end{array}$ & 2001 \\
\hline 78 & Nilsson, Kristian & $\begin{array}{l}\text { Do Fundamentals Explain the Behavior of the Real } \\
\text { Effective Exchange Rate? }\end{array}$ & 2002 \\
\hline 79 & Bharat, Barot & $\begin{array}{l}\text { Growth and Business Cycles for the Swedish Econ- } \\
\text { omy }\end{array}$ & 2002 \\
\hline 80 & Bharat, Barot & $\begin{array}{l}\text { House Prices and Housing Investment in Sweden } \\
\text { and the United Kingdom. Econometric Analysis for } \\
\text { the Period 1970-1998 }\end{array}$ & 2002 \\
\hline 81 & Hjelm, Göran & $\begin{array}{l}\text { Simultaneous Determination of NAIRU, Output } \\
\text { Gaps and Structural Budget Balances: Swedish Evi- } \\
\text { dence }\end{array}$ & 2003 \\
\hline
\end{tabular}




\begin{tabular}{|c|c|c|c|}
\hline 82 & $\begin{array}{l}\text { Huhtala, Anni and Eva } \\
\text { Samalkovis }\end{array}$ & Green Accounting, Air Pollution and Health & 2003 \\
\hline 83 & Lindström, Tomas & $\begin{array}{l}\text { The Role of High-Tech Capital Formation for } \\
\text { Swedish Productivity Growth }\end{array}$ & 2003 \\
\hline 84 & $\begin{array}{l}\text { Hansson, Jesper, Per } \\
\text { Jansson and Mårten Löf }\end{array}$ & $\begin{array}{l}\text { Business survey data: do they help in forecasting the } \\
\text { macro economy? }\end{array}$ & 2003 \\
\hline 85 & $\begin{array}{l}\text { Boman, Mattias, Anni } \\
\text { Huhtala, Charlotte Nils- } \\
\text { son, Sofia Ahlroth, Gö- } \\
\text { ran Bostedt, Leif Matt- } \\
\text { son and Peichen Gong }\end{array}$ & $\begin{array}{l}\text { Applying the Contingent Valuation Method in Re- } \\
\text { source Accounting: A Bold Proposal }\end{array}$ & \\
\hline 86 & Gren, Ing-Marie & $\begin{array}{l}\text { Monetary Green Accounting and Ecosystem Ser- } \\
\text { vices }\end{array}$ & 2003 \\
\hline 87 & $\begin{array}{l}\text { Samakovlis, Eva, Anni } \\
\text { Huhtala, Tom Bellander } \\
\text { and Magnus Svarteng- } \\
\text { ren }\end{array}$ & $\begin{array}{l}\text { Air Quality and Morbidity: Concentration-response } \\
\text { Relationships for Sweden }\end{array}$ & 2004 \\
\hline 88 & $\begin{array}{l}\text { Alsterlind, Jan, Alek } \\
\text { Markowski and Kristian } \\
\text { Nilsson }\end{array}$ & $\begin{array}{l}\text { Modelling the Foreign Sector in a Macroeconomet- } \\
\text { ric Model of Sweden }\end{array}$ & 2004 \\
\hline 89 & Lindén, Johan & The Labor Market in KIMOD & 2004 \\
\hline 90 & $\begin{array}{l}\text { Braconier, Henrik and } \\
\text { Tomas Forsfält }\end{array}$ & $\begin{array}{l}\text { A New Method for Constructing a Cyclically Ad- } \\
\text { justed Budget Balance: the Case of Sweden }\end{array}$ & 2004 \\
\hline 91 & $\begin{array}{l}\text { Hansen, Sten and To- } \\
\text { mas Lindström }\end{array}$ & Is Rising Returns to Scale a Figment of Poor Data? & 2004 \\
\hline 92 & Hjelm, Göran & $\begin{array}{l}\text { When Are Fiscal Contractions Successful? Lessons } \\
\text { for Countries Within and Outside the EMU }\end{array}$ & 2004 \\
\hline 93 & $\begin{array}{l}\text { Östblom, Göran and } \\
\text { Samakovlis, Eva }\end{array}$ & $\begin{array}{l}\text { Costs of Climate Policy when Pollution Affects } \\
\text { Health and Labour Productivity. A General } \\
\text { Equilibrium Analysis Applied to Sweden }\end{array}$ & 2004 \\
\hline 94 & $\begin{array}{l}\text { Forslund Johanna, Eva } \\
\text { Samakovlis and Maria } \\
\text { Vredin Johansson }\end{array}$ & $\begin{array}{l}\text { Matters Risk? The Allocation of Government Subsi- } \\
\text { dies for Remediation of Contaminated Sites under } \\
\text { the Local Investment Programme }\end{array}$ & 2006 \\
\hline 95 & $\begin{array}{l}\text { Erlandsson Mattias and } \\
\text { Alek Markowski }\end{array}$ & $\begin{array}{l}\text { The Effective Exchange Rate Index KIX - Theory } \\
\text { and Practice }\end{array}$ & 2006 \\
\hline 96 & $\begin{array}{l}\text { Östblom Göran and } \\
\text { Charlotte Berg }\end{array}$ & The EMEC model: Version 2.0 & 2006 \\
\hline 97 & $\begin{array}{l}\text { Hammar, Henrik, } \\
\text { Tommy Lundgren and } \\
\text { Magnus Sjöström }\end{array}$ & $\begin{array}{l}\text { The significance of transport costs in the Swedish } \\
\text { forest industry }\end{array}$ & 2006 \\
\hline 98 & Barot, Bharat & $\begin{array}{l}\text { Empirical Studies in Consumption, House Prices } \\
\text { and the Accuracy of European Growth and Infla- } \\
\text { tion Forecasts }\end{array}$ & 2006 \\
\hline 99 & Hjelm, Göran & $\begin{array}{l}\text { Kan arbetsmarknadens parter minska jämviktsar- } \\
\text { betslösheten? Teori och modellsimuleringar }\end{array}$ & 2006 \\
\hline 100 & $\begin{array}{l}\text { Bergvall, Anders, To- } \\
\text { mas Forsfält, Göran } \\
\text { Hjelm, } \\
\text { Jonny Nilsson and Ju- } \\
\text { hana Vartiainen }\end{array}$ & $\begin{array}{l}\text { KIMOD } 1.0 \text { Documentation of NIER's Dynamic } \\
\text { Macroeconomic General Equilibrium Model of the } \\
\text { Swedish Economy }\end{array}$ & 2007 \\
\hline
\end{tabular}




\begin{tabular}{|c|c|c|c|}
\hline 101 & Östblom, Göran & $\begin{array}{l}\text { Nitrogen and Sulphur Outcomes of a Carbon Emis- } \\
\text { sions Target Excluding Traded Allowances - } \\
\text { An Input-Output Analysis of the Swedish Case }\end{array}$ & 2007 \\
\hline 102 & $\begin{array}{l}\text { Hammar, Henrik and } \\
\text { Asa Löfgren }\end{array}$ & $\begin{array}{l}\text { Explaining adoption of end of pipe solutions and } \\
\text { clean technologies - Determinants of firms' invest- } \\
\text { ments for reducing emissions to air in four sextors } \\
\text { in Sweden }\end{array}$ & 2007 \\
\hline 103 & $\begin{array}{l}\text { Östblom, Göran and } \\
\text { Henrik Hammar }\end{array}$ & $\begin{array}{l}\text { Outcomes of a Swedish Kilometre Tax. An Analysis } \\
\text { of Economic Effects and Effects on NOx Emis- } \\
\text { sions }\end{array}$ & 2007 \\
\hline 104 & $\begin{array}{l}\text { Forsfält, Tomas, Johnny } \\
\text { Nilsson and Juhana } \\
\text { Vartianinen }\end{array}$ & $\begin{array}{l}\text { Modellansatser i Konjunkturinstitutets medelfrist- } \\
\text { prognoser }\end{array}$ & 2008 \\
\hline 105 & Samakovlis, Eva & $\begin{array}{l}\text { How are Green National Accounts Produced in } \\
\text { Practice? }\end{array}$ & 2008 \\
\hline 107 & $\begin{array}{l}\text { Forslund, Johanna, Per } \\
\text { Johansson, Eva Sama- } \\
\text { kovlis and Maria Vredin } \\
\text { Johansson }\end{array}$ & $\begin{array}{l}\text { Can we by time? Evaluation. Evaluation of the } \\
\text { government's directed grant to remediation in Swe- } \\
\text { den }\end{array}$ & 2009 \\
\hline 108 & $\begin{array}{l}\text { Forslund, Johanna } \\
\text { Eva Samakovlis, Maria } \\
\text { Vredin Johansson and } \\
\text { Lars Barregård }\end{array}$ & $\begin{array}{l}\text { Does Remediation Save Lives? } \\
\text { On the Cost of Cleaning Up } \\
\text { Arsenic-Contaminated } \\
\text { Sites in Sweden }\end{array}$ & 2009 \\
\hline 109 & $\begin{array}{l}\text { Sjöström, Magnus and } \\
\text { Göran Östblom }\end{array}$ & $\begin{array}{l}\text { Future Waste Scenarios for Sweden on the Basis of } \\
\text { a CGE-model }\end{array}$ & 2009 \\
\hline 110 & Österholm, Pär & $\begin{array}{l}\text { The Effect on the Swedish Real Economy of the } \\
\text { Financial Crisis }\end{array}$ & 2009 \\
\hline 111 & Forsfält, Tomas & $\begin{array}{l}\text { KIMOD } 2.0 \text { Documentation of changes in the } \\
\text { model from January } 2007 \text { to January } 2009\end{array}$ & 2009 \\
\hline 112 & Österholm, Pär & $\begin{array}{l}\text { Improving Unemployment Rate Forecasts Using } \\
\text { Survey Data }\end{array}$ & 2009 \\
\hline 113 & Österholm, Pär & $\begin{array}{l}\text { Unemployment and Labour-Force } \\
\text { Participation in Sweden }\end{array}$ & 2009 \\
\hline 114 & $\begin{array}{l}\text { Jonsson, Thomas and } \\
\text { Pär Österholm }\end{array}$ & $\begin{array}{l}\text { The Properties of Survey-Based } \\
\text { Inflation Expectations in Sweden }\end{array}$ & 2009 \\
\hline 115 & $\begin{array}{l}\text { Hjelm, Göran and Kris- } \\
\text { tian Jönsson }\end{array}$ & $\begin{array}{l}\text { In Search of a Method for Measuring the Output } \\
\text { Gap of the Swedish Economy }\end{array}$ & 2010 \\
\hline 116 & Vartiainen, Juhana & Interpreting Wage Bargaining Norms & 2010 \\
\hline
\end{tabular}

